sion to IUGG as inter-association symposia or IAPSO symposia for the August 1991 General Assembly of the IUGG in Vienna, Austria. These included polar shelf drainage processes, polar ice and water masses, results of recent Antarctic oceanographic field work, and results from the CEAREX (Coordinated Eastern Arctic Experiment). It was recognized that the last three of these topics are likely to be included in either geographically-oriented or program-oriented sessions at the IUGG meeting.

Effective coordination efforts with other associations will require that Commission members be well informed on similar activities being planned or contemplated by other groups. A listing of such groups and of all known or anticipated future meetings was compiled. All meetings falling within the sphere of interest of the Commission are listed, as soon as they are announced, on the ICE.OCEAN bulletin board which is maintained on Omnet telemail for this purpose, and is available globally to members of the sea ice and oceanographic community. It was suggested that the Commission maintain on the same board a listing of current high priority research topics, cross-referencing those that are the subject of ongoing, planned or proposed international programs, to inform researchers of other programs related to their own.

The second annual meeting of the Commission will take place in Bergen, Norway, in conjunction with the October 1989 Workshop on Regional and Mesoscale Modelling of Ice-Covered Oceans.

\section{A memento of Amundsen}

\section{G. Hattersley-Smith \\ The Crossways, Cranbrook, Kent TN17 2AG UK}

\section{Received March 1989}

A silver spoon commemorating Roald Amundsen recently came into my possession. An interesting story hangs by this particular spoon but, first, a brief description of a finely crafted piece of silverware.

The spoon is $13 \mathrm{~cm}$ long and the bowl $3.5 \mathrm{~cm}$ wide. On the decorated front, near the top, there is a portrayal of the great explorer with, in raised letters, his name 'Roald Amundsen' above and the date '14 December 1928' below: that was the day of his national commemoration, ie the anniversary of the day and month on which he reached the South Pole. Immediately below this, there is a portrayal of the Latham biplane in which he was lost on 18 June 1928.

At the top and bottom of the bowl are the inscriptions 'Sydpolen 1911' and 'Nordpolen 1926'. Along the back of the spoon are engraved the words 'Fra Norske venner 12 Mars 1929' [From Norwegian friends 12 March 1929], preceded by the hall-mark ' 830 S B NM'.

The spoon had originally belonged to the late Lieut $\mathrm{CdrC}$. H.Payne, $\mathrm{RN}$, and reference to the Navy List shows that, in 1928-29, this officer was serving as Commissioned Gunner in HMS Harebell (Capt. A. Cochrane), a sloop of 1190 tons designated Fishery Protection 'cruiser' at that time. Reference to the 'Pink List', giving the movements of HM ships at sea, shows that Harebell was in harbour at Kirkenes for a few days following 8 March 1929. Rear-Adm. G. A. Thring, CB DSO, who was serving as Third Lieutenant in Harebell at the time, now takes up the story in a recent letter which he has kindly allowed me to quote, and which vividly recalls the rigours of service during a little known episode in Arctic naval history:

Harebell had been sent to protect our trawlers fishing off the Murman Coast because the Russians had been unfriendly. Kirkenes was our base, and we had to have a Norwegian icebreaker to get us into harbour. It was very cold about minus $30^{\circ} \mathrm{F}$. We coaled there and bought some provisions, the sailors did not appreciate reindeer! During the two hours of daylight we ski-ed, and found the Norwegians most hospitable. There was a small unit of soldiers who challenged us to a rifle shooting competition. Our team were beaten but were presented with the spoons..also with copious drams of schnapps! My Amundsen spoon is sitting in the sugar basin now as I write ... I am sorry that I could not say we were engaged in searching for Amundsen, but 1 consider we richly deserved those spoons lying in the snow and freezing cold!

The standard mark on the spoon indicates $83 \%$ silver. I thank Mr Arne Hartmark, of Frammuseet, Oslo, for the information that the other two symbols in the hall-mark are respectively the trademark and initials used by the makers, Kunst \& Metalindustri $\mathrm{A} / \mathrm{S}$, of Trondheim, the letters 'NM' standing for 'Norsk Metalindustri' but no longer in use. 